\section{IJ§ER}

ISSN: 2149-5939
International Journal of Social Sciences and Education Research

Online, http://dergipark.gov.tr/ijsser

Volume: 3(3), 2017

\title{
Türkiye ve İtalya'da öğretmenlik mesleği: Karşılaştırmalı bir analiz ${ }^{1}$
}

\author{
Teaching profession in Turkey and Italy: A comparative analysis
}

\author{
Mehmet Metin Arslan²
}

\section{$\ddot{O} z$}

Received Date: 20/ 03 / 2017

Accepted Date:10 / 06 / 2017

Bu çalışmanın amacı, Türkiye ile İtalya'daki öğretmenlik mesleğinin benzerlik ve farklılıklarının karşılaştırılmalı bir analizini yapmaktır. Bu amaç kapsamında İtalya ve Türkiye'deki öğretmenlik mesleğinin başlangıç eğitimi, profili, istihdamı, maaşları ve değerlendirilmesi açısından karşılaştırmalı bir analiz yapılmıştır. Yapılan analiz sonucunda her iki ülkede de öğretmenlik başlangıç eğitimi, yükseköğretim düzeyinde eş zamanlı ve ardışık uygulamalarla gerçekleşmektedir. İtalya ve Türkiye'de genelde öğretmenler kadındır. Yaş dă̆ılımı bakımından İtalya'da ögretmenler yaşll, Türkiye'de gençtir. İtalya'da ögretmenler yarışma stnaviyla, Türkiye'de ise seçme sınavlyla mesleğe alınmaktadır. Ülkelerin ögretmen maaşları OECD ortalamasının altındadır. Öğretmenin degerlendirilmesinde Türkiye'de okul müdürü, Italya'da ise ögretmen değerlendirme komitesi ve okul müdürü sorumludur.

Anahtar sözcükler: karşılaştırmalı eğitim, öğretmenlik mesleği, istihdam, maaş, değerlendirme

\begin{abstract}
The aim of this study is to make a comparative analysis of the similarities and differences of the teaching profession in Turkey and Italy. Within this scope, a comparative analysis has been made in terms of initial training, profile, employment, salaries and evaluation of the teaching profession in Italy and Turkey. As a result of this analysis, the initial training for teaching position in both countries takes place simultaneously and successively at higher education level. The teachers in Italy and Turkey are generally female. In terms of age distribution, teachers are older in Italy and younger in Turkey. Teachers in Italy are employed via a competition exam and via a selection exam in Turkey. Salaries of teachers in both countries are below the OECD average. In terms of evaluation of teacher; school principal has the authority in Turkey to evaluate the teachers, whereas in Italy this is shared by teacher evaluation committee and the school principal.
\end{abstract}

Keywords: Comparative education, teaching profession, employment, salary, evaluation

\section{Giriş}

Günümüzde, ülkelerin eğitim sistemlerini kapsamlı olarak inceleyen karşıllaştırmalı eğitim çalışmalarının önemi her geçen gün artmaktadır. Bu alanda yapılan karşılaştırma çalışmaları ülkelerin eğitim politikalarına ve uygulamalarına 1şık tutmaktadır. Karşılaştırmalı eğitim araştırmalarında ülkelerin eğitim sistemlerinin genel özellikleri incelendiğinde, özellikle de öğretmenlik mesleğinin önemi ve mesleğin ulusal ve uluslararası boyutlarda değerlendirilme şekli hakkında bilgi sahibi olunmaktadır. Öğretmenlik mesleğinin önemi, günümüzde bütün toplumlar

\footnotetext{
${ }^{1}$ Bu Çalışma 27-29 Nisan 2017 tarihinde yapılan ICSSER - 3. ${ }^{\text {rd }}$ International Conference on Social Sciences and Education Research'de sözlü bildiri olarak sunulmuştur.

${ }^{2}$ Doç. Dr., Kırıkkale Üniversitesi, Eğitim Fakültesi, Eğitim Bilimleri Bölümü, Eğitim Yönetimi ve Denetimi Anabilim Dal1, mehmetmetinarslan1@gmail.com
} 
Arslan, M.M. (2017). Teaching Profession in Turkey and Italy: A Comparative Analysis. International Journal of Social Sciences and Education Research, 3(3), 761-771.

tarafindan bilinmekte ve mesleğin yeterliklerini belirleyip mesleki gelişimi sağlamaya yönelik çabalar aralıksız sürmektedir. Bu duruma koşut olarak öğretmenlik mesleği birçok boyutuyla ülkelerin gündeminde sürekli yer almaktadır. Ülkelerin öğretmen yetiştirme politikalarının belirlenmesi, öğretmenlerin hizmet öncesi ve hizmetiçi eğitimi, istihdamı, denetimi ve performanslarının değerlendirilmesi, kariyer basamakları öğretmen eğitimi kapsamında değerlendirilen boyutları oluşturmaktadır.

Öğretmenler, birçok ülkede kamu görevlileri arasında en kalabalık kesim olarak hizmet vermektedir. Türkiye'de kamuda çalışan memurlar hizmet sınıfına göre değerlendirildiğinde en kalabalık grubun "eğitim-öğretim sınıfı" olduğu görülmektedir. Toplam kamu çalışanı sayısının 888.503 kişisi eğitim-öğretim hizmetleri sınıfında görev yapmaktadır. Bu sayı kamu çalışanlarının \% 35,81'ini oluşturmaktadır (http://www.dpb.gov.tr). Eğitim-öğretim hizmetleri sınıfını, eğitim kurumu yöneticisi ve kadrolu öğretmen oluşturmaktadır. Milli Eğitim Bakanlığında Aralık 2016 itibarıyla 68.086 eğitim kurumu yöneticisi, 814.262 kadrolu öğretmen ve 17.820 sözleşmeli öğretmen görev yapmaktadır (Milli Eğitim Bakanlığı;MEB, 2016).

Karşılaştırmalı eğitim çalışmaları incelendiğinde öğretmenlik mesleği, Türkiye gibi pek çok ülkede de farklı açılardan sıkça gündeme gelen bir konu olmuştur. Ülkelerin kamuoyunda, öğretmenlik mesleği ve meslekle ilgili yürütülen çalışmalar ile yapılan uygulamalar hep sorgulanmıştır. Yapılan araştırmalarda gelişmiş ve gelişmekte olan ülkelerin öğretmenlik mesleğine yükledikleri anlam ve statünün benzerliklerine rağmen ülkeler arasındaki farklılıklar da dikkat çekici niteliktedir.

Son yıllarda Avrupa Birliği ülkeleri içerisinde hem eğitim sistemi hem de öğretmenlik mesleğinin geliştirilmesi konularının sürekli tartışıldığı bir ülke olması bakımından İtalya'daki öğretmenlik mesleğinin değerlendiriliş biçimi ile Türkiye'deki uygulamaların karşılaştırılması, bu çalışmanın amacıdır. Bu kapsamda Türkiye ve İtalya eğitim sisteminde öğretmenlik mesleğinin benzerlik ve farklılıkları, karşılaştırmalı bir yaklaşımla incelenecektir.

Bu amaç çerçevesinde şu sorulara cevap aranmaya çalışılmıştır: Türkiye ve İtalya'da;

1. Öğretmenlik mesleğinin başlangıç eğitimi ve profili açısından benzerlik ve farklılıkları nelerdir?

2. Öğretmen istihdamı ve maaşlar açısından benzerlik ve farklılıkları nelerdir?

3. Öğretmen değerlendirmesi bakımından benzerlik ve farklılıkları nelerdir?

\section{Yöntem}

Çalışma konusu karşılaştırmalı eğitim olan bu araştırma, Türkiye ile İtalya'daki öğretmenlik mesleğini benzerlik ve farklılıklarıyla karşılaştırmalı çözümlemesini amaçladığından tarama modelindedir.

Çalışma, İtalya ve Türkiye eğitim sistemlerindeki öğretmenlere ilişkin verilerle sınırlandırılmıştır. Çalışmada özellikle Ekonomik İşbirliği ve Kalkınma Teşkilatı (OECD), Avrupa Eğitim Bilgi A ğı (EURYDICE) gibi kurumların resmî raporları, yayınları ve verileri temel alınmıştır. Türkiye ile ilgili verilere ulaşmak için ilgili kuruluşların yayınlarından yararlanılmıştır. Çalışmada öncelikle Türkiye ve İtalya eğitim sistemi bütün boyutlarıyla incelenmiş, öğretmenlik mesleği ayrıntılı olarak analiz edilmiştir. Ayrıca her iki ülkenin de eğitim bakanlıklarının kaynaklarından veriler elde edilmeye çalışılmıştır. Elde edilen verilerin çözümlenmesinde, 
Arslan, M.M. (2017). Türkiye ve İtalya'da Öğretmenlik Mesleği: Karşılaştırmalı Bir Analiz. International Journal of Social Sciences and Education Research, 3(3), 761-771.

ülkelerin araştırmayla ilgili verileri değerlendirilmiş ve karşılaştırmalar yapılmıştır. Türkiye ile ilgili yorumları genişletebilmek için ilgili kamu kurum ve kuruluşların dokümanlarından da yararlanılmıştır.

\section{Bulgular}

$\mathrm{Bu}$ bölümde araştırma kapsamında karşılaştırılan İtalya ve Türkiye'deki öğretmenlik mesleğinin başlangıç eğitimi, profili, istihdamı ve değerlendirilmesi gibi verilere yer verilecektir.

\section{İtalya ve Türkiye'deki Öğretmenlik Mesleğinin Başlangıç Eğitimi ve Profili}

İtalya ve Türkiye'de öğretmenlerin başlangıç eğitimi yüksek öğretim düzeyde gerçekleşmekte ve programlar bir yüksek lisans derecesine ulaşılmasına da imkân sağlamaktadır. İlk ve ortaöğretim öğretmenliğinin gerekli koşulu lisans derecesidir. Her iki ülkede de öğrenciler yükseköğrenimlerinin başından itibaren belli bir öğretmen eğitimine eş zamanlı olarak katılmaktadırlar. Ortaöğretim öğretmenliği için yükseköğretimde belli bir alanda öğrenim görmüş öğrenciler ardışık olarak ayrı bir aşamada mesleki eğitime devam ederler. Genel ve mesleki bileșeni bulunan öğretmen eğitimi eș zamanlı veya ardıșık olarak düzenlenir. Bu iki bileşenin nasıl bir araya geldiğine bağlı olarak mesleki bileşen genel bileşenle eş zamanlı sağlanabilir (eş zamanlı model). Bu modelde öğrenciler yükseköğrenimlerinin başından itibaren belli bir öğretmen eğitimine katılırlar. Ardışık model ise yükseköğretimde belli bir alanda öğrenim görmüş öğrenciler eğitimin sonunda veya sonrasında mesleki eğitime devam ederler. Eş zamanlı modelle eğitim almak için lise diploması gereklidir. Bazı durumlarda yükseköğretim veya öğretmen eğitimi yetenek sertifikası olanlar da bu eğitime katılabilir(Avrupa Komisyonu/EACEA/Eurydice, 2013). Her iki ülkede de öğretmenlere meslek hayatlarının ilk yıllarında zorluklarla karşılaşmamaları için yapılandırılmış adaylık programları uygulanır. Adaylık zorunlu bir süreçtir. Aday öğretmenlerinin geçmesi gereken zorunlu bu deneme sürecinde değerlendirme vardır.

İtalya'da okul öncesi ve ilköğretim için başlangıç öğretmen eğitimi eş zamanlı olarak düzenlenir. Bu uygulama, okul öncesi ve ilköğretim öğretmenliği için Türkiye'de de aynıdır. Ortaöğretim öğretmenliğinde ise İtalya'da öğretmen adayları lisans derecesini tamamladıktan sonra belirli bir alanda ardışık olarak uzmanlaşma okuluna devam etmektedirler. Bu okula adaylar yazılı ve sözlü olarak iki kademeli sınavla alınmaktadır(https://webgate.ec.europa.eu). Türkiye'de ise ortaöğretim öğretmenliği için yükseköğretim programlarına devam eden veya mezun olan ve belirlenen şartları taşıyan adaylar için yükseköğretim kurumlarında pedagojik formasyon eğitimi sertifika programı düzenlenmektedir.

Öğretmenlerin cinsiyet, yaş ve emeklilik yaşı gibi profil bilgilerine bakıldığında her iki ülkede de ilkokul ve ortaokul öğretmenleri genelde kadındır. Bu durum İtalya'da ilkokulda $\% 95$, ortaokulda $\% 77$, lisede ise $\% 62$ 'dir. Türkiye'de ise ilköğretimde $\% 52$, lisede $\% 42$ 'dir (https://webgate.ec.europa.eu). Öğretmenlerin yaş dağılımına bakıldığında İtalya'da öğretmen nüfusunun oldukça yaşlı olduğu, 50 yaş üstü öğretmenlerin oranının yarıya yakın olduğu söylenebilir. Ortaöğretim kurumlarında çalışan öğretmenlerin yaş ortalamalarının genel olarak temel eğitimde çalışan öğretmenlerin yaş ortalamalarından yüksek olduğu görülmektedir. OECD ülkeleri arasında 40 yaş ve üzerinde yüksek bir oranla İtalya gelmektedir. 40 yaş ve üzeri öğretmenlerin en düşük olduğu ülke ise Türkiye'dir. Genel olarak bakıldığında İtalya'da öğretmen nüfusunun büyük çoğunluğunun yaşl1, Türkiye'de ise genç olduğu söylenebilir.(OECD, 2016). 
Arslan, M.M. (2017). Teaching Profession in Turkey and Italy: A Comparative Analysis. International Journal of Social Sciences and Education Research, 3(3), 761-771.

Her iki ülke için öğretmen iş gücünün boyutuna dair bir gösterge olan öğrenci/öğretmen oranı İtalya' da ilköğretimde 11,3, ortaöğretimde 12'dir( Eurydice, 2016). Türkiye'de ise ilköğretimde 16, ortaöğretimde 13'e düşmüştür(MEB,2016).

\section{İtalya ve Türkiye'de Öğretmen İstihdamı ve Maaşları}

İtalya'da kamuoyunun tepkiyle karşıladığ 1 yönetişim anlayışı çerçevesinde eğitim alanında birçok reform çalışması yapılmaktadır. İtalyan Hükümeti, Temmuz 2015'te "İyi Okul” (La buona scuola) olarak anılan ulusal eğitim ve öğretim sistemindeki reformu kabul etmiştir. Eğitim ve öğretim tedarik yönetimi ile müfredatın çeşitli yönlerini değiştirmeyi öngören bu yasala sisteme yeni uygulamalar getirilmiştir. Yasa öğretmenlerle ilgili yetiştirme ve değerlendirme için hükümler getirmekte ve öğretmenler için iş başında zorunlu eğitim öngörmektedir. Bu yasayla öğretmen maaşlarının öğrencilerin başarılarına göre bir değerlendirmeyle belirlenmesi kabul edilmiştir. Ülkede eğitimin özelleştirilmesinin hedeflenmesi ve devlet okullarında yapılan bütçe kesintileri nedeniyle eğitimde eşitsizlik tırmanmıştır. Öğretmen sendikaları, eğitim çalışanları ve öğrenciler eğitimde firsat eşitsizliğini besleyen eğitim politikalarını ve devlet okullarındaki kötü şartları protesto etmek için bütün ülkede eylem yapmışlardır (http://www.trthaber.com; http://www.dailymotion.com).

İtalya'da Temmuz 2015'te yürürlüğe konulan okul reformu, öğretmenlerin istihdamı ile ilgili olarak işe alım sisteminin değiştirilmesini de düzenlemektedir. Bu ülkede 2016 yılından itibaren açık yarışmalar yoluyla mesleğe erişime izin vermesi olumlu bir önlem olarak görülmüştür. İtalyan Anayasası uyarınca açık yarışmalar yolu ile işe alma öğretmenlik mesleğine girmenin standart yoludur. Bu uygulama, öğretmenlerin çoğunun, kısa süreli sözleşmelerle çalıştıktan sonra herhangi bir yarışmadan geçerek sürekli görevlere yerleştirilmesi anlamına gelmektedir (European Commission/ EACEA/Eurydice, 2016). Okullardaki boş kadrolara alınacak öğretmenler yarışmalar yolu ile belirlenir. Yeni uygulamada öğretmenler okul müdürlerinden iş teklifi aldıktan sonra öz geçmişleri, deneyimleri ve becerilerini içeren bilgiler sunacaklar. Öğretmenler okulların kendilerine yaptığı teklifleri kabul edebilir, reddedebilir. Şayet öğretmen tarafından bir öneri yoksa Bölgesel Okul Ofisi öğretmene bir okul tahsis eder. Okulun önerisini kabul ederse öğretmen üç yıllık bir süre için okula atanır. Öğretmenlik alanlarının hepsinde daimi sözleşmeli öğretmen istihdam edilmez. Bazı alanlarda geçici sözleşmeyle öğretmen çalıştırılır. Geçici sözleşmeli öğretmenler her yıl boş kalmış yerlerde görevlendirilir. Öğretmenler il düzeyindeki aday listelerden okul yönetimi tarafından işe alınır. Daimi kadrodaki öğretmenlerin kısa devamsızlıklarını karşılamak için bu sürede geçici sözleşmeli öğretmenleri, okul yöneticileri işe alırlar. Türkiye'de öğretmenlerin büyük çoğunluğu devlet memuru statüsünde, İtalya'da ise sözleşmeli devlet memuru statüsünde istihdam edilmektedir (EACEA/Eurydice, 2016).

İtalya'da öğretmenlerin kariyer beklentileri, kariyer sistemi yalnızca kıdeme dayalı sabit maaş artışlarıyla belirlendiğinden sınırlıdır. Öğretmenler ancak, mesleği bırakarak okul yöneticisi veya eğitim müfettişliğine geçerek kariyer ilerlemesi sağlayabilirler. Okul düzeyinde belirlenen kriterlere göre, okullarda belirli görevleri üstlenen öğretmenlere ekstra ücret verilmektedir. İtalya'da kıdem temelli kariyer sistemiyle maksimum maaşa ancak 35 yıllık hizmetin ardından ulaşılabilmektedir. OECD ortalaması 25 yıldır. Öğretmen maaşları, yüksek öğrenimli diğer kamu çalışanlarının kazançlarından daha düşüktür. $\mathrm{Bu}$ durum İtalya'da öğretmenlik mesleğinin statüsünün düşük ve mesleğe olan ilginin az olduğunun göstergesidir (Education and Training Monitor. Italy, 2016; OECD,2016). 
Arslan, M.M. (2017). Türkiye ve İtalya'da Öğretmenlik Mesleği: Karşılaştırmalı Bir Analiz. International Journal of Social Sciences and Education Research, 3(3), 761-771.

Türkiye'de öğretmenlik mesleği, adaylık döneminden sonra öğretmen, uzman öğretmen ve başöğretmen olmak üzere üç kariyer basamağına ayrılır. Resmi eğitim kurumlarına aday öğretmen olarak atanabilmek için; Devlet Memurları Kanunu'nda (657 Sayılı Kanun, madde 48) belirtilen genel şartların yanı sıra Millî Eğitim Bakanlığı Öğretmen Atama ve Yer Değiştirme Yönetmeliği’nde belirlenen özel şartlar aranır.

Millî Eğitim Bakanlığı Öğretmen Atama ve Yer Değiştirme Yönetmeliği’nin 5. maddesine göre, öğretmenlerin atanma koşulları şunlardır (Resmi Gazete, 17 Nisan 2015: 29329):

a) Öğretmenlik mesleğine aday ögretmen olarak girilir.

b) Aday öğretmenliğge/ögretmenliğe atanacaklarda, 657 Sayll Kanun'un 48'inci maddesinde belirtilen genel şartların yanında aşağıdaki özel şartlar aranır:

c) Mezun olunan yükseköğretim programının, Bakanlı̆̆ın öğretmenliğe atanacakların tespitine ilişkin kararına göre atama yapılacak alana uygun olmasl,

c) Öğretmenliğe kaynak teşkil eden yükseköğretim programlarından mezun olanların ihtiyacı karşılamadığı alanlara atanacaklar hariç olmak üzere, Bakanlıkça uygun görülen pedagojik formasyon eğitiminin başarılla tamamlanmış olması,

d) Yurt dişındaki yükseköğretim kurumlarından mezun olanların, Yükseköğretim Kurulu Başkanlığınca yükseköğrenimlerinin ve/veya pedagojik formasyon belgelerinin yurt içindeki yükseköğretim kurumlarına veya programlarına denkliğinin kabul edilmiş olması,

e) İlk atama kapsamında atanacakların, KPSS'den atanacakları alanlar için belirlenen taban puan ve üzerinde puan almış olmaları,

f) Devlet memurluğundan veya öğretmenlik mesleğinden çlkarllmayl gerektiren bir ceza alınmamış olması.

Öğretmenlik Alan Bilgisi Testi ilki 2013 yllında 15 alanda "Kamu Görevlerine İlk Defa Atanacaklar İçin Yapılacak Sinavlar Hakkında Genel Yönetmelik" kapsamında gerçekleştirilmiştir. 2016 yılı için Öğretmenlik Alan Bilgisi Testi 17 öğretmenlik alanında (Türkçe, İlköğretim Matematik, Fen Bilimleri/Fen ve Teknoloji, Sosyal Bilgiler, Türk Dili ve Edebiyat1, Tarih, Coğrafya, Lise Matematik, Fizik, Kimya, Biyoloji, Din Kültürü ve Ahlak Bilgisi, Yabancı Dil/Almanca, İngilizce, Rehber Öğretmenliği, Sınıf Öğretmenliği ve Okul öncesi Öğretmenliği) planlanmış olup, sınav Öğrenci Seçme Yerleştirme Merkezi (ÖSYM) tarafından yapılmıştır.

Öğretmen atamaları, Milli Eğitim Bakanlığı tarafindan öğretmen istihdam projeksiyonları kapsamında sayısal olarak belirlenen branşlar çerçevesinde; KPSS sınav sonuçları ve adayların il ve okul tercihleri dikkate alınarak gerçekleştirilmektedir. Sonuçlar Milli Eğitim Bakanlı̆̆ tarafindan elektronik ortamda adaylara açık olarak ilan edilmektedir.

1739 sayılı Milli Eğitim Temel Kanunu'nun 43. Maddesinde yapılan değişiklikle (01.03.20146528/5md.) aday öğretmenlerin değerlendirilmesi şöyle belirtilmektedir (Resmi Gazete, $24.06 .1973: 14574)$ :

Aday öğretmenler, en az bir yll fiilen çalı̧̧mak ve performans değerlendirmesine göre başarılı olmak şartlarını sağlamak kaydıyla, yapılacak yazılı veya yazılı ve sözlü sınava girmeye hak kazanırlar. Uygulanacak olan sözlü sinavda aday öğretmenler;

a) Bir konuyu kavraylp özetleme, ifade kabiliyeti ve muhakeme gücü,

b) İletişim becerileri, öz güveni ve ikna kabiliyeti,

c) Bilimsel ve teknolojik gelişmelere açıklı̆̆ 
Arslan, M.M. (2017). Teaching Profession in Turkey and Italy: A Comparative Analysis. International Journal of Social Sciences and Education Research, 3(3), 761-771.

c) Topluluk önünde temsil yeteneği ve eğitimcilik nitelikleri yönlerinden Bakanlıkça oluşturulacak komisyon tarafindan değerlendirilir.

Aday öğretmenlerden sınavda başarılı olanlar, öğretmen olarak atanır. Başarılı olamayanlar ise il içinde veya dışında bir okulda görevlendirilerek bir yılın sonunda değerlendirmeye tekrar tabi tutulurlar. Aday öğretmenlik süresi sonunda sınava girmeye hak kazanamayanlar ile üst üste iki defa sınavda başarılı olamayanların memuriyetle ilişiği kesilir.

Millî Eğitim Bakanlığına bağlı okullardaki öğretmen istihdamı daimi (kadrolu) atama şeklinde olmaktadır. $\mathrm{Bu}$ okullardan öğretmen açı̆̆ı olanlara geçici statüde de öğretmen görevlendirilmektedir. Yaygın uygulama biçimi "daimi” statüde, "yaşam boyu" iş garantisine sahip öğretmenliktir. Türkiye'de çalışan öğretmenlerin çalışma koşulları farklı yasa ve kurumlar tarafından belirlenmektedir. Bu bağlamda; tüm öğretmenler mesleki statü, mesleğe giriş, çalışma zamanları ve tatiller, maaş ve emeklilik durumları bakımından öncelikle Devlet Memurları Kanunu, Sosyal Güvenlik Kurumu Kanunu gibi genel yasalara tabidirler. Bunun yanında öğretmenlerin, görev tanımları, mesleki gelişimleri, çalışma takvimler, tatilleri, hizmet içi eğitimleri vb. konularda özel hukuki metinler bulunmaktadır.

İtalya'da Temmuz 2015'te okul reformu ile öğretmenlerin maaşları ile ilgili olarak liyakate dayalı bileşenlerin ve tüm öğretmenlerin mecburi sürekli mesleki gelişimine yönelik uygulama başlatılmıştır. 2016'dan itibaren, her okuldaki en iyi performans gösteren öğretmenlerin bir defaya mahsus iyi performans göstermek ilkesine dayanarak bonus toplaması sağlanmıştır.

Genel olarak ifade edilecek olursa, öğretmen maaşları bakımından OECD ülkeleri içerisinde en düşük ülkelerden birisi Türkiye'dir. Mesleğe yeni başlayan bir okul öncesi öğretmeninin Türkiye'de elde ettiği maaş OECD ortalamasından 3500 ABD doları daha düşüktür. Türkiye'de öğretmenlere bölgesel farklılıklara bağlı ek ödeme yapılmamaktadır. Oysa Türkiye, coğrafi bölgeleri arasında gelişmişlik farkları olan ülkedir. İtalya'da bu durum dikkate alınmakta ve ek ödeme yapılmaktadır. 2013 yılı OECD satın alma gücü paritesi verilerine göre (OECD; Education at a Glance, 2015 ) İtalya ve Türkiye'deki okul öncesi, ilköğretim ve ortaöğretim öğretmenlerinin başlangıç ve on beş yıllık öğretmen maaşları satın alma gücüne dönüştürülmüş yıllık maaş (ABD Doları) olarak aşağıda verilmiştir:

\begin{tabular}{|l|c|c|c|c|c|c|}
\hline & \multicolumn{2}{|c|}{ Okul öncesi } & \multicolumn{2}{c|}{ Ilköğretim } & \multicolumn{2}{c|}{ Ortaöğretim } \\
\hline & Başlangıç & 15 yıllık & Başlangıç & 15 yıllık & Başlangıç & 15 yıllık \\
\hline İtalya & 27509 & 33230 & 27509 & 33230 & 29655 & 36207 \\
\hline Türkiye & 25295 & 27139 & 24295 & 27139 & 26266 & 28110 \\
\hline OECD Ort. & 28730 & 38653 & 29807 & 41425 & 31013 & 42825 \\
\hline
\end{tabular}

Merkez bankası verilerine göre 2013 yılı sonu dolar alış 2134 TL , 2016 yılı sonu dolar alış 3525 TL olarak belirlenmiştir (http/www.tcmb.gov.tr). Her iki ülke de OECD ortalamasının altındadır. Öğretmenlerin maaşları ile ilgili 2015/2016 yılı Avrupa Komisyonu Raporu (Teachers' and School Heads' Salaries and Allowances in Europe - 2015/16) incelendiğinde İtalya'da başlangıç temel maaş ilköğretim öğretmenleri için 23051 Euro, 27 yıllık öğretmen için 33884 Euro olarak gösterilmektedir. Türkiye'de ise başlangıç temel maaş ilköğretim öğretmenleri için 13496 Euro, 27 yıllık öğretmen için 16541 Euro olarak belirlenmiştir. İtalya'da hükümetler 2010 
Arslan, M.M. (2017). Türkiye ve İtalya'da Öğretmenlik Mesleği: Karşılaştırmalı Bir Analiz. International Journal of Social Sciences and Education Research, 3(3), 761-771.

yılından 2013 yılına kadar kamu açığını azaltmak için öğretmen maaşlarını dondurdu. Bu durum sonraki yıllarda da bütçeyi dengelemek amacıyla maaşlara yansıtıldı (EACEA/Eurydice, 2016).

Milli Eğitim Bakanlığı'na bağlı okul ve kurumlarda kadrolu olarak çalışan öğretmenler 657 sayılı Devlet Memurları Kanunu'nun "eğitim-öğretim hizmetleri sınıfı" içinde yer alır, maaşları da bu sınıfa ve derecelerine/kademelerine göre belirlenir. Öğretmenlere, her eğitim ve öğretim yılı başında bir kez "eğitim-öğretime hazırlık ödeneği” ödenmektedir. Bu ödeneğin miktarı her yıl artırılmaktadır. 2016-2017 eğitim ve öğretim yılında 1.000 TL'ye yükseltilmiştir. Ana maaş ödemesine ek olarak, haftalık zorunlu ders yükünü aşan öğretmenlere, girdiği her ek ders saati için ek ders ücreti ödenmektedir. Yabancı dil seviyesi belirli puanın üzerinde olan öğretmenlere de "yabanc1 dil tazminat" ödenir.

Her iki ülkede de öğretmen sendikalarının, öğretmenlerin mali ve özlük haklarının belirlenmesinde karar süreçlerine katılmaları söz konusudur.

\section{İtalya ve Türkiye'de Öğretmen Performansının Değerlendirmesi}

İtalya'da öğretmen değerlendirmesinden genelde okul yöneticisi sorumludur. Bireysel öğretmen değerlendirmesi sadece adaylık sürecinin sonunda yapılır. Müfettiş ya da okul dışından kişilerin gözlemlerinin öğretmen değerlendirilmesi için kullanılmadığı ülkedir.

Okul müdürü, okulun öğretmen değerlendirme komitesince belirlenen ölçütleri kullanarak performans değerlendirmesi yapmaktadır. Öğretmen değerlendirme komitesi okul müdürü; üç öğretmen; harici bir değerlendirici (başka bir okuldan bir öğretmen veya başkan veya bir müfettiş); iki okul aile birliği temsilcisi (ilkokul öncesi, ilköğretim ve alt orta öğretim okullarında) veya bir veli temsilcisi ve bir öğrenci temsilcisinden (orta öğretim okullarında) oluşur (European Commission, 2015 )

Türkiye'de aday öğretmenlik uygulamasında danışman öğretmen, okul müdürü ve maarif müfettişi değerlendirme yapmaktadır. Öğretmenler ise sadece okul müdürü tarafından değerlendirilmektedir. Geçmişte öğretmen değerlendirmede çoklu denetim mekanizması söz konusu idi. Öğretmenler, "Bakanllğa bağlı her derece ve türden eğitim kurumunda görev yapan ve adaylık sürecini tamamlamış olan öğretmenlerin başarı, verimlilik ve gayretlerini ölçmek üzere her ders yılı sonunda, görev yaptığı eğitim kurumunun müdürü tarafindan değerlendirmesi yapılır." hükmü gereğince değerlendirilmektedir. Değerlendirme kriterleri 5 basamaklı; "Hiçbir zaman (0), Nadiren (1), Bazen(2), Sıklıkla(3), Her zaman (4)" olarak puanlanıyor. On başlıkta 50 madde olarak belirlenen mesleki ölçütler, okul müdürünce değerlendirilmektedir. Öğretmenlerin performansı "mesleki bilgi", "mesleki beceri" ile "tutum ve değerler" olmak üzere üç alanda değerlendirilmektedir.

\section{Sonuç ve tartışma}

Öğretmenlik mesleğini daha fazla geliştirmeye yönelik hem Türkiye'de hem de İtalya'da mesleğe ilişkin nesnel ve bilimsel verilere dayalı birçok çalışma yapılmaktadır. İtalya ve Türkiye'deki öğretmenlik mesleğinin başlangıç eğitimi, profili, istihdamı ve değerlendirilmesi gibi bulgular incelendiğinde her iki ülkede de başlangıç eğitimi yüksek öğretim düzeyindedir. $\mathrm{Bu}$ ülkelerde eş zamanlı veya ardışık olarak düzenlenen başlangıç eğitiminin genel ve mesleki bileşeni vardır. Eş zamanlı eğitim her iki ülkede de okul öncesi ve ilköğretim öğretmenleri için uygulanmaktadır. Ortaöğretim öğretmenliğine ardışık eğitimle hazırlanılmaktadır. İtalya'da 
Arslan, M.M. (2017). Teaching Profession in Turkey and Italy: A Comparative Analysis. International Journal of Social Sciences and Education Research, 3(3), 761-771.

lisans derecesini alan adaylar ardışık olarak uzmanlaşma okuluna devam etmektedirler. Bu okula giriş için adaylar yazılı ve sözlü iki kademeli sınava girerler. Türkiye'de ise belirlenen şartları taşıyan lisan mezunları veya lisansa devam eden adaylar yükseköğretim kurumlarından pedagojik formasyon eğitimi alırlar. Her iki ülkede de mesleğe yeni başlayan öğretmenlere yönelik zorunlu olarak adaylık(staj) eğitimi uygulanmaktadır. Adaylık eğitiminin sonunda değerlendirme vardır. Öğretmenlerin profil bilgilerine bakıldı̆̆ında, her iki ülkede de öğretmenler genelde kadındır. Yaş dağılımına bakıldığında ise İtalya'da öğretmen nüfusunun yaşlı, Türkiye'de ise genç olduğu söylenebilir.

Elde edilen verilere bakıldığında öğretmenlerin istihdamı ile ilgili olarak İtalya'da öğretmen alım sistemi 2015'te yürürlüğe giren okul reformu ile değişmiştir. Öğretmenler yarışma sınavıyla mesleğe alınmaktadır. Sözleşmeli olarak birkaç yıl çalıştıktan sonra daimi kadroya atanmaları sağlanmaktadır. Öğretmenler okullara öz geçmişlerini, deneyimlerini ve yeterliklerini içeren bilgileri sunarlar. Okulun teklifini kabul eden öğretmenler üç yıllık bir süre için okullara atanır. İtalya'da öğretmenlerin kariyer beklentileri sınırlı olup, maaşlar yüksek öğrenimli diğer çalışanlardan az olması nedeniyle mesleğin statüsü düşüktür. Türkiye'de ise öğretmen istihdamında farklı uygulamalar bulunmaktadır. Öğretmenliğe atanacaklarda Devlet Memurları Kanunu'nun genel şartlarının yanında özel şartlar da aranır. İlk defa atanacakların KPSS sınavından aldıkları puanın öğretmenlik alanları için belirlenen taban puandan fazla olması gerekmektedir. Atamalar belirlenen öğretmenlik branşlarına il ve okul tercihler ile KPSS puanları değerlendirilerek yapılır. Milli Eğitim Bakanlığına bağlı okullara atanan öğretmenler daimi kadroya atanmaktadır. Özel okullarda görev alan öğretmenler ise sözleşmeli çalışmaktadır.

Her iki ülkede de maaşlar ve çalışma koşullarında öğretmen sendikaları söz sahibidir. İtalya ve Türkiye'de öğretmenin aldığı maaş OECD ortalamasının altındadır. Hatta Türkiye'de ödenen maaşların son yıllarda dövizdeki artışlar dikkate alındığında OECD 2013 yılı verilerine göre iyice azaldığı görülmektedir.

İtalya'da öğretmenlerin mesleki gelişimine yönelik uygulama kapsamında performansları değerlendirilmekte iyi performansa bonus verilmektedir. Genel değerlendirildiğinde İtalya'da öğretmen maaşı aynı seviyede eğitim almış çalışanların maaşlarından daha azdır.

Bu durum Türkiye'de ise ülke standartlarına göre iyi, uluslararası standartlara göre ise diğer meslektaşlarından daha az kazandığ 1 ifade edile bilinir. İtalya'da 27 yıllık tecrübesi olan bir ilkokul öğretmeni yıllık 33884 Euro maaş alırken, Türkiye'de aynı hizmet yılındaki bir ilkokul öğretmeni ise yıllık 16541 Euro maaş almaktadır. Bu miktar aynı tecrübedeki İtalya'daki öğretmenin yaklaşık yarısı kadardır. Türkiye'de maaş giderlerinin ve kaynak dağılımındaki 'çarpıklı̆̆ın' giderilmesi amacıyla öğretmenlerin ücretlerinin yeniden gözden geçirilmesi gerekmektedir.

Öğretmenin performansını değerlendirilmesi İtalya ve Türkiye'de farklılıklar gösterir. Her iki ülkede de öğretmen değerlendirilmesinden okul yöneticisi sorumludur. Ancak İtalya'da değerlendirme sürecine öğretmen değerlendirme komitesi de katılır. Okul müdürü, okulun öğretmen değerlendirme komitesince belirlenen ölçütleri kullanarak performans değerlendirmesi yapmaktadır. Türkiye'de ise okul müdürü ders yılı sonunda bakanlıkça belirlenen ölçütlere göre öğretmenin performansını değerlendirmektedir.

Her iki ülkedeki öğretmenlik mesleğine yönelik uygulamalar benzerlikler içerse de İtalya'daki uygulamalardan yararlanıla bilinir. Türkiye'de mesleğe gösterilen ilgi yüklenilen anlam yüksek 
Arslan, M.M. (2017). Türkiye ve İtalya'da Öğretmenlik Mesleği: Karşılaştırmalı Bir Analiz. International Journal of Social Sciences and Education Research, 3(3), 761-771.

olsa da istihdam koşulları, maaş düşüklüğ̈̈ ve performans değerlendirme süreçlerinin öncelikle tartışılıp yeniden düzenlenmesi gerekmektedir. İstihdam koşulları öğretmende bulunması gereken çağdaş yeterlikler dikkate alınarak düzenlenmelidir. Maaşlar belirlenirken OECD ortalamaları dikkate alınmalı, performansa dayalı ücretlendirme gerçekleştirilmelidir.

\section{Kaynakça}

Avrupa Komisyonu/EACEA/Eurydice (2013). Avrupa'da Öğretmenler ve Okul Liderlerine İlișkin Temel Veriler. Eurydice Raporu. Luxembourg: Publications Office of the European Union (Erişim tarihi: $05.03 .2017)$.

Devlet Personel Başkanlığı, http://www.dpb.gov.tr/tr-tr/istatistikler/kamu-personeli-istatistikleri (Erişim tarihi: 02 .03.2017).

Dailymotion (Euornews Türkçe) (yayım tarih:08.10.2016).http://www.dailymotion.com/video/italya-daogrenciler-ayaklandi. (Erişim tarihi: 02.02. 2017).

European Commission/ Eurydice, Countries Description of national education systems. https://webgate.ec.europa.eu/fpfis/mwikis/eurydice/index.php/Countries(Erişim tarihi: 10.4.2017)

European Commission (2016). Education and Training Monitor. Italy 2016 https://ec.europa.eu/ education/sites/education/files/monitor2016-it_en.pdf.(Erişim tarihi: 04.04.2017)

European Commission/EACEA/Eurydice, (2016). Teachers' and School Heads' Salaries and Allowances in Europe - 2015/16. Eurydice Facts and Figures. Luxembourg: Publications Office of the European Unio. (Erişim tarihi: 05 .03. 2017).

European Commission/(2015), Education and Training Monitor. İtalya 2015, http://ec.europa.eu/ dgs/education_culture/repository/education/tools/docs/2015/monitor15-vol-2_en.pdf,(Erişim tarihi:05 .03. 2017)

Milli Eğitim Temel Kanunu (1739).T.C. Resmi Gazete, 24.06.1973:14574

Millî Eğitim Bakanlığı Öğretmen Atama ve Yer Değiştirme Yönetmeliği. T.C. Resmi Gazete, 17 Nisan 2015: 29329

MEB (2016). 2017 Yll Bütçe Görüşmeleri http://sgb.meb.gov.tr/meb iys dosyalar (Erişim tarihi: 05.04.2017).

OECD(2015), Education at a Glance 2015: Oecd Indicators, OECD Publishing. http://dx.doi.org/10.1787/eag-2015-en(Erişim Tarihi: 10.03. 2017).

OECD (2016), Education at a Glance 2016: OECD Indicators. http://www.oecd-ilibrary.org/ education/education-at-a-glance-2016_eag-2016-en (Erişim tarihi: 11.03. 2017).

Türkiye Cumhuriyeti Merkez Bankası, Gösterge Niteliğindeki Merkez Bankası Döviz Kurları, http://www.tcmb.gov.tr/ $w p s / w c m / c o n n e c t / T C M B+T R / T C M B+T R / M a i n+M e n u / I s t a t i s t i k l e r, \quad$ (Erişim Tarihi: 02 04. 2017).

Türkiye Radyo Televizyon Kurumu, TRT HABER, (yayım tarih:05.05.2015) http://www.trthaber.com/ haber/dunya/italyada-egitim-reformuna-protesto-182914.html, (Erişim Tarihi:02.04.2017). 
Arslan, M.M. (2017). Teaching Profession in Turkey and Italy: A Comparative Analysis. International Journal of Social Sciences and Education Research, 3(3), 761-771.

\section{Extended abstract in English}

Comparative education studies, which examine countries' education systems with all of their dimensions, shed light on countries' education policies and practices. In parallel with this, the profession of teaching is always in the agenda of the countries with its many dimensions. The teaching profession in Italy was selected for comparison in order to develop proposals appropriate to the teaching profession of the Turkish Education System. The reason for selecting Italy is the fact that in recent years there has been a constant debate within the European Union on the development of both the education system and the teaching profession. In recent years, there have been many reform studies in the field of education in Italy, which have been reacted against by the public opinion. Within the scope of the study, data such as initial training, profile, employment, salaries and evaluation of teaching profession in Turkey and Italy were used.

In Italy and Turkey, initial training of teachers is realized at higher education level. In both countries, students attend in a specific teacher training concurrently at the beginning of higher education. For secondary school teachers, students with a certain background in higher education continue to pursue vocational training in successive stages. Teacher training has a general and professional component. Considering the profile information of the teachers, primary and middle school teachers in both countries are generally female. When we consider the age distribution of the teachers, it is seen that the teacher population in Italy is old whereas younger in Turkey. Italy is at the forefront among OECD countries with 40 years and above. Turkey is the country with lowest number of teachers with 40 years and above. In general, two third of teachers are below 40 years.

The School Reform Act, which was enacted in July 2015 in Italy, allows access to the profession through open contests since 2016. Permanent contract teachers do not cover all available areas. Temporary contract teachers are assigned to vacant places each year. Teachers are hired by the school administration through the candidate lists at provincial level. Temporary contract teachers are hired by school administrators during this period to meet the short-term absence of permanent teachers (webgate.ec.europa.eu, 2016). Teachers' career expectations in Italy are limited because the career system is determined only by senior salary increases. Based on criteria set at school level, extra salary payments are awarded to teachers who undertake specific tasks in schools. Teacher salaries are lower than those of other public employees with higher education. This indicates that the opinions about teaching profession in Italy are low (European Commission, 2016). There are various applications in Turkey to become a teacher at preschool level and other levels. Teachers are appointed under special conditions determined by the Ministry of National Education as well as the general conditions stated in the Civil Servants Law. The types of employment of teachers at the schools under Ministry of National Education are generally as permanent assignment, as it can take the form of temporary assignment when needed. The prevalent form is "permanent" status. Teachers under permanent status have the "life long" job guarantee. 
Arslan, M.M. (2017). Türkiye ve İtalya'da Öğretmenlik Mesleği: Karşılaştırmalı Bir Analiz. International Journal of Social Sciences and Education Research, 3(3), 761-771.

The salaries of teachers in Turkey and Italy are below the OECD average. In both countries, teachers' unions participate in the decision making process of teacher salaries and working conditions. In Turkey there is no additional payment to the teachers due to regional differences. However, Turkey is a country with significant developmental differences between its regions. In Italy, this is...

In Italy, school principal is generally responsible for teachers' evaluation. Individual teacher evaluation is done only at the end of candidacy period. The school principal performs a performance evaluation using the criteria set by the school teacher evaluation committee. The teacher evaluation committee consists of school principal, three teachers, an external evaluator (a teacher or principal from another school or an inspector); two main attorneys (Primary school, primary and lower secondary schools) or a parent representative and a student representative (secondary school) (European Commission, Italy, 2015). Teacher candidates in Turkey are evaluated by a consultant teacher, school principal and inspector from ministry. The performance of the permanent teachers in Turkey is assessed according to the criteria determined by the ministry at the end of the school year. 